\title{
Isolation of a Strain of Mycobacterium Tuberculosis \\ Sensitive to Penicillin
}

\author{
Sang Jae Kim and Sung Chin Kim \\ Korean Institute of Tuberculosis, Korean National Tuberculosis Association
}

\section{Penicillin 感受性 結核菌의 分離}

\author{
大韓結核協會 結核研究院 \\ 金台材・金成鎮
}

結核菌 (Mycobacterium tuberculosis) 은 penicillin 分解醅素를 生產하기 때 문에 이抗生劑에 對해서 高度: 의 耐性을 난타낸다. 이러한 菌의 닌 狀이 이菌의 分離培養에 있어서 雜菌污染을 減少시키기 위해 penicillin 을 使用할 수 있게끔 해주고 있다.

著者등은 本研究院이 最近에 開發한 KIT(Korean Institute of Tuberculosis 의 略字)培養基를 他培養基 와 比較實驗하면서 雜菌污染 防止를 위해 加해준 penicillin 에 感受性을 나타내는 結核菌을 分離하였기에, 報告하는 바이다.

螢光顯微鏡檢査로 抗酸菌의 含有를 確認한 喀疢 65 件을 penicillin $\mathrm{G} 100 \mathrm{U} / \mathrm{ml}$ 가 든 培養基와 들어있지 않은 培養基에 培養한 결과 그中 2 件이 penicillin 含有培養基에서 菌發育이 없었다. 그런데 그中 1 件은 再 探取한喀痰과 一次分離培養에서 penicillin 含有하지 않은 培養基에 發育한 菌株로 再檢査한 결과 penicillin 耐性菌임이 밝혀졌다. 그러나 다른 1件은 10 回 以上의 再採取喀疢과 15 代 以上 繼代培養한 菌株로 再檢査 했으나 penicillin 에 높은 感受性을 나타내었다. 이菌株는 KIT 培養基上에서 $10 \sim 15 \mathrm{U} / \mathrm{ml}$ 에 感受性을 나 타내는데 비해 브통 penicillin 耐性結核菌은 $1000 \mathrm{U} / \mathrm{ml}$ 에서도 發育할 수 있다. L-J 培養基에서는 感受性 이 $2 \sim 5$ 倍 더 높았다.

이菌의 penicillinase 活性을 다른 penicillin 耐结結核菌과 比較해 본 결과 後者의 菌은 强한 penicillinase 活性을 낙타내어 penicillin 分子를 파괴하는데 비해서 前者의 菌은 이醳素의 活性이 매우 弱하거나 陰往이 었다. 따라서 이菌의 penicillin 感受性은 penicillinase 活性의 減少에 侬해 일어나는 現象이라고 生覺 한다.

contamination rate in the culture examina-

\section{Summary}

In an experiment to assess the effectiveness of antibiotic penicillin in reducing the tion of sputum specimens, we incidentally discovered the existence of tubercle bacilli highly sensitive to penicillin by culturing the decontaminated specimen on both peni- 
cillin-free and -containing media. Two of 65 direct-smear positive sputa examined failed to yield positive culture on the medium containing $100 \mathrm{U} / \mathrm{ml}$ of penicillin. One of these showed as much resistance as those of resistant isolates on subsequent reexamination with either recollected sputum or a subculture from the penicillin-free, primary isolation medium.

However, the other one remained sensitive on the repeated examination with either recollected sputum or a subculture. This strain failed to grow in the presence of as little as 10 to $50 \mathrm{U} / \mathrm{ml}$ of penicillin while the resistant organisms could tolerate up to 1000 $\mathrm{U} / \mathrm{ml}$ in the KIT medium*. In the L-J medium, however, the organisms showed 2 to 5 times as much sensitivity as that in the KIT medium.

A reference strain, H37Rv, and clinical isolates resistant to penicillin showed strong penicillinase activity while this enzyme of penicillin-sensitive isolate was very weak or negative, suggesting that the penicillin sensitivity of the strain might be due to inability to destroy penicillin molecules.

\section{Introduction}

It is generally accepted that Mycobacterium tuberculosis and several other species of mycobacteria are highly resistant to penicillin because of their ability to produce penicillinase ${ }^{1,3,7)}$. This has facilitated the use of antibiotic penicillin in primary culture of mycobacteria from sputum specimens in conjunction with the various decontamination $\because$ procedures to protect the culture medium from being contaminated by unwanted bacteria ${ }^{4,5}$.

Accordingly, we designed an experiment to assess the effectiveness of this antibiotic in reducing the contamination rate on the culture examination of sputum specimens using a new medium formulated recently in this laboratory. The new medium was named "KIT medium" (KIT is an abbreviation for the Korean Institute of Tuberculosis). From part of this study we discovered the existence of tubercle bacilli highly sensitive to penicillin by culturing the decontaminated specimen on both penicillin-free and -containing media. In the present paper we describe such an unusual isolate of $M$. tuberculosis.

\section{Materials and Methods}

\section{Culture Examination of Sputum Specimens:}

Sixty five sputum specimens from 65 patients, confirmed to contain acid-fast bacilli by fluorescence microscopy were submitted for processing and examination. Most of these specimens were collected from the patients registered in health centers in Seoul city and referred to our laboratory for culture examination in order to monitor the patient's response to chemotherapy.

Approximately $3 \mathrm{ml}$ of sputum was mixed with an equal volume of $4 \% \mathrm{NaOH}$ in a

\footnotetext{
* The KIT medium was recently formulated in this laboratory by the author. The base solution of the medium contained the following ingredients: $\mathrm{KH}_{2} \mathrm{PO}_{4}, 2.7 \mathrm{~g} ; \mathrm{Na}_{2} \mathrm{HPO}_{4}, 1.0 \mathrm{~g}$; sodium glutamate, $0.9 \mathrm{~g}$; pyruvic acid, $0.1 \mathrm{~g}$; distilled water, $100 \mathrm{ml}$. To prepare the medium, $200 \mathrm{ml}$ of homogenized whole eggs, $6 \mathrm{ml}$ of $2 \%$ malachite green, and $4 \mathrm{ml}$ of glycerine were added to $100 \mathrm{ml}$ of the base solution. After dispensing the medium was inspissated at 85 to $90 \mathrm{C}$ for one hour.
} 
Table 1. Drugs and their concentrations used for drug sensitivity testing.

\begin{tabular}{lllcrrr}
\hline \multirow{2}{*}{ Drugs } & \multicolumn{5}{c}{ Concentrations $\left(\mathrm{ug} / \mathrm{ml}^{*}\right.$ or $\mathrm{U} / \mathrm{ml}^{* *}$ ) } \\
\cline { 2 - 7 } & \multicolumn{2}{c}{ For H37Rv } & \multicolumn{4}{c}{ For test strain } \\
\hline Isoniazid $^{*}$ & 025 & 0.05 & 0.1 & 0.2 & 1 & 5 \\
Streptomycin $^{*}$ & 2.5 & 5 & 10 & 10 & 20 & 40 \\
p-Aminosalicylic acid $^{*}$ & 0.125 & -0.25 & 0.5 & 1 & 2 & 4 \\
\hline Penicillin & 5 & 10 & 50 & 100 & 500 & 1000 \\
\hline
\end{tabular}

${ }^{* *}$ Not differing concentrations used for $\mathrm{H} 37 \mathrm{Rv}$ and test strain.

McCarteny bottle and the mixture was homogenized and digested for $15 \mathrm{~min}$. Part of the digested specimen was used to inoculate two slopes of both Ogawa $\left(3 \% \mathrm{KH}_{2} \mathrm{PO}_{4}\right)$ and KIT media free of or containing $100 \mathrm{U} / \mathrm{ml}$ of penicillin without neutralization. We designated this procedure as the simple method. After diluting the remaining specimen with sterile distilled water, the mixture was centrifugalized for $15 \mathrm{~min}$ at $3000 \mathrm{rpm}$. The liquid was decanted from the sediment and sterile $\mathrm{M} / 1.5$ phosphate buffer $(\mathrm{pH}, 7.0)$ was added to resuspend and neutralize the sediment. This concentrated specimen was used to inoculate two slopes of three media free of or containing penicillin; LöwensteinJensen(L-J) medium, Ogawa medium, and KIT midium. This procedure was designated as the concentration method. The inoculated media were incubated at $37 \mathrm{C}$ for 24 to 48 hours in a horizontal position with a loose cap to allow the inoculum to spread and become fixed onto the medium surface and evaporate excess water in the medium. Incubation was continued for at least 8 weeks, with weekly examination, before discarding as negative. Colonies which had formed on the inoculated media and morphologically resembled those of $M$. tuberculosis were subjected to niacin test, cord formation test and $p$-nitrobenzoic acid sensitivity test in order to confirm the species.

Drug Sensitivity Test: The sensitivity to varying concentrations of penicillin, of the organisms which yielded negative result on the penicillin containing medium in the initial culture examination, was determined with either recollected sputum or a subculture from the penicillin free, primary isolation medium, by either direct or indirect test. The direct test was performed by inoculating the concentrated specimen onto the media containing penicillin. Sediment from the digested and centrifugalized specimen ( $3 \mathrm{ml}$ of sputum used) was suspended in about $0.5 \mathrm{ml}$ of sterile $\mathrm{M} / 1.5$ phosphate buffer, if the specimen contained 1 to 5 bacilli per microscopic field on fluorescence microscopy, and a drop of this suspension was inoculated onto a slope of medium. If the specimen contained 2 or more bacilli per microscopic field, the concentrated specimen was suspended in 1 or more $\mathrm{ml}$ of buffer solution. The indirect test was performed by using a subculture from the penicillin-free, primary isolation medium. A loopful of bacterial mass (about $1 \mathrm{mg}$ in wet weight) from the growth on the L-J medium for 3 weeks was placed in a $1 / 4$ oz bottle containing 6 glass beads $(2-3 \mathrm{~mm}$ in diameter) 
Table 2. Comparison of culture results of 65 smear-positive sputum specimens between the media and between the techniques.

\begin{tabular}{cccccc}
\hline \multirow{2}{*}{ Medium } & \multicolumn{2}{c}{ Simple method } & & \multicolumn{2}{c}{ concentration } \\
\cline { 2 - 3 } & Positive & Negative & & Positive & Negative \\
\hline L-J & N D & N D & & $60(92.3)$ & $5(7.7)$ \\
L-J+penicillin & N D & N D & & $58 \cdot(89.2)$ & $7(10.8)$ \\
Ogawa & $62(95.4)$ & $3(4.6)$ & & $57(87.7)$ & $8(12.2)$ \\
Ogawa+penicillin & $60(92.3)$ & $5(7.7)$ & & $55(84.6)$ & $10(15.4)$ \\
KIT & $62(95.4)$ & $3(4.6)$ & & $60(92.3)$ & $5(7.7)$ \\
KIT+penicillin & $60(92.3)$ & $5(7.7)$ & & $58(89.2)$ & $7(10.8)$ \\
\hline
\end{tabular}

${ }^{*}$ ND-Not done.

${ }^{* *}$ Numbers in parentheses represent percent.

and $0.5 \mathrm{ml}$ of sterile distilled water and the bottle was vigorously shaked on a Voltex mixer for $1 \mathrm{~min}$. An additional $4.5 \mathrm{ml}$ of sterile distilled water was then added to this bacillary homogenate and a loopful of the bacillary suspension was inoculated onto the medium by a loop of $3 \mathrm{~mm}$-external diameter made from nichrome wire (24 SWG) af ter coarse bacillary clumps settled down. The sensitivity to major antituberculous drugs of a penicillin-sensitive isolate was determined by the indirect test. The inoculated media were incubated at $37 \mathrm{C}$ for 4 weeks. The presence of 50 or more colonies on the drug-containing medium was taken as an indication that the strain is resistant. The drugs and their concentrations used are as shown in Table 1. Interpretation of the test for the sensitivity to antituberculous drugs was made by the resistance-ratio method ${ }^{2}$.

Penicillinase Activity Test: The culture to be tested were grown on the L-J medium for 3 weeks. About $20 \mathrm{mg}$ of bacterial mass (wet weight) was suspended in $1 \mathrm{ml}$ of $\mathrm{M}$ / 15 phosphate buffer $(\mathrm{pH}, 6.8)$. To this suspension penicillin $\mathrm{G}$ was added creating a final concentration of $50 \mathrm{~J} / \mathrm{ml}$. The suspen- sion was incubated for $15,30,60,90$, and 120 min periods at $37 \mathrm{C}$. With microcaps, $0.05 \mathrm{ml}$ of the suspension was transferred to each well of a three-welled nutrient agar plate. The plate had been preseeded with a penicillin-sensitive strain of Staphylococcus aureus (obtained from the National Institute of Health, Seoul, Korea). The bacterial suspension without added penicillin was also tested as control. A $50 \mathrm{U} / \mathrm{ml}$ of penicillin $\mathrm{G}$ was also tested as the standard. After allowing the antibiotic to diffuse for 3 hours at room temperature, the plates were incubated for 24 hours at $37 \mathrm{C}$. The zones of growth inhibition were measured.

\section{Results}

Culture examination of 65 direct-smear positive sputa by the concentration method produced 60 positive cultures on the L-J medium and the KIT medium but yielded fewer positive cultures(57) on the Ogawa medium as shown in Table 2. The simple method, however, yielded 62 positive cultures on both Ogawa and KIT media. Beyond our expectations, the simple method produ- 
ced two more positive cultures. Longer duration of processing in the concentration method might have inflicted injury on the organisms in these two specimens. The organisms in three specimens, which failed to grow on the Ogawa medium by the concentration method, showed good growth on the same medium when cultured by the simple method. Three specimens failed to give positive result on all three media in both culture techniques. Whether these specimens were false positive under fluorescence microscopy or contained non-cultivable organisms was not determined.

Although one slope contamination was found occasionally, there were too few contaminations to allow comparison between both media with or without penicillin and/ or between the techniques. This might be due to treatment of the specimen with $4 \%$ $\mathrm{NaOH}$ which is strong enough to kill almost all contaminants present in the sputum specimens.

Of the three media used in this experiment, our KIT medium seems to have certain

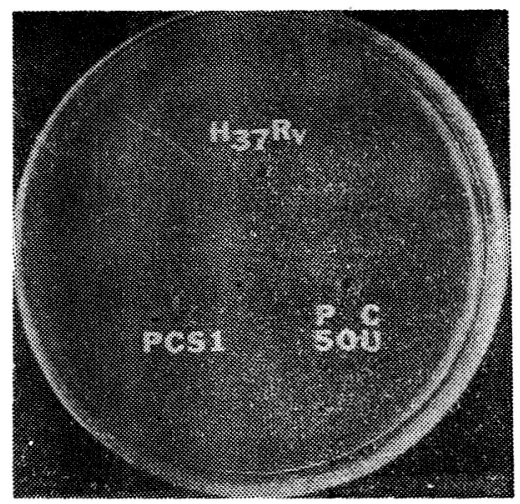

Fig. 1. Inhibitory zone of $S$. aureus by the residual amounts of penicillin in the penicillinbacterial cell suspension after one hour reaction. H37Rv: a reference resistant strain. PCS1: penicillin-sensitive isolate. PC 50: the standard $50 \mathrm{U} / \mathrm{ml}$ of penicillin.
Table 3. Sensitivity to penicillin of the penicillin -sensitive and -resistant strains of: Mycobacterium tuberculosis.

\begin{tabular}{lcc}
\hline $\begin{array}{l}\text { Strains } \\
\text { tested }\end{array}$ & $\begin{array}{c}\text { Medium } \\
\text { used }\end{array}$ & $\begin{array}{c}\text { Minimal inhibitory } \\
\text { concentration(U/ml) }\end{array}$ \\
\hline H37Rv & K I T & $>1000^{*}$ \\
L - J & $>1000^{*}$ \\
\hline PCR1 & K I T & $>1000^{*}$ \\
& L - J & $>1000^{*}$ \\
\hline PCS1 & K I T & $10-50$ \\
& L - J & $5-10$ \\
\hline
\end{tabular}

*--This concentration could not inhibit the growth of the strains tested.

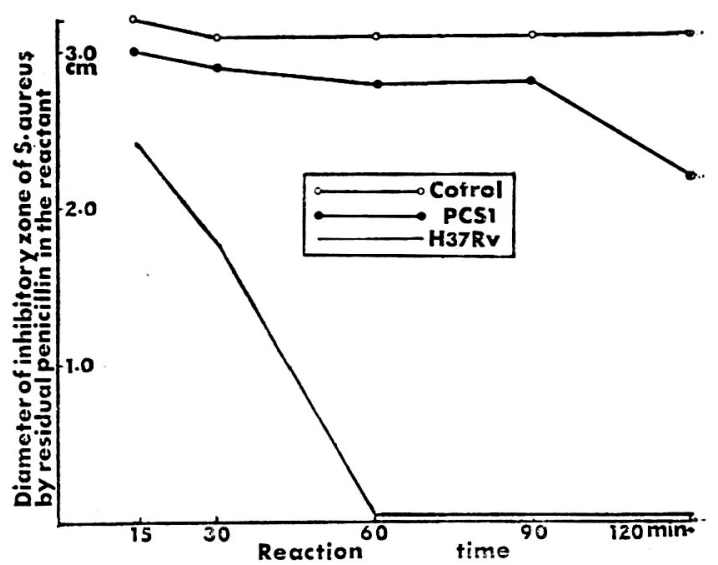

Fig. 2. Penicillinase activity of the strains H37Rv and PCS1 of $M$. tuberculosis by varying reaction time. Control: $50 \mathrm{U} / \mathrm{ml}$ of penicillin solution.

advantages. The growth of tubercle bacilli on this medium was visible 4 to 6 days earlier than on either L-J or Ogawa medium. Also, the KIT medium yielded the same. number of positive cultures as the Ogawa medium had in the simple method and as. the L-J medium had in the concentration method.

The most important observation from this: study was the discovery of penicillin-sensi- 
tive tubercle bacilli. Two out of 65 specimens showed negative growth on the penicillin medium in primary culture examination. The penicillin had no inhibitory effect to tubercle bacilli except for the growth of the organisms in these two specimens. Neither the time taken to first growth appearance nor the number of colonies formed of penicillin-resistant organisms differed between the penicillin-free and-containing media. One of two cases, however, showed resistance to $100 \mathrm{U} / \mathrm{ml}$ of penicillin on subsequent reexamination with either recollected sputum or a subculture from the penicillin-free, primary isolation medium. The other one remained sensitive on the repeated examination with either recollected sputum or a subculture. This strain(PCS1) failed to grow at concentration of as 10 to $50 \mathrm{U} / \mathrm{ml}$ of penicillin while the resistant organisms, H37Rv and PCR1, could tolerate up to 1000 $\mathrm{U} / \mathrm{ml}$ in the KIT medium as shown in Table 3. In the L-J medium, however, the organisms were inhibited at 2 to 5 times lower concentration of the antibiotic than that in the KIT medium.

The patient who excreted such unusual organism(PCS1) had taken isoniazid, $p$-aminosalicylic acid, and streptomycin for nine months without bacteriological improvement of the disease. The strain PCS1, therefore, was resistant to isoniazid and $p$-aminosalicylic acid but remained sensitive to streptomycin. Whether this patient was infected with organisms primarily resistant to the drugs and, for this reason, responded poorly to the chemotherapy given, is not known due to lack of information.

The examination of penicillinase activity revealed that penicillin-resistant strain
$\mathrm{H} 37 \mathrm{Rv}$ destroyed all of penicillin molecules in the penicillin-bacillary suspension after one hour reaction at $37 \mathrm{C}$ thus no inhibitory zone of $S$. aureus was observed around the well as shown in Figure 1. To the contrary penicillin-sensitive strain PCS1 could not destroy penicillin molecules at all or else destroyed a lesser amount of the antibiotic, thus the inhibitory zone was observed around the well. Only slight decrease in the amount of intact molecules was observed in the penicillin-bacillary suspension of sensitive strain PCS1 even after 2 hours of reaction as shown in Figure 2. The penicillinresistant strain $\mathrm{H} 37 \mathrm{Rv}$, on the other hand, destroyed all of the penicillin molecules during 30 to $60 \mathrm{~min}$ of reaction time.

\section{Discussion}

From this study we could not find any difference in the contamination rates between the penicillin-free and-containing media because the specimen was decontaminated with $4 \% \mathrm{NaOH}$ which is strong enough to kill most contaminants. However, beyond our expectations, penicillin inhibited the growth of certain strains of $M$. tuberculosis in primary culture examination of sputum specimens. One of two cases, which showed no growth on the medium containing $100 \mathrm{U} / \mathrm{ml}$ of penicillin in primary culture examination, was found to be resistant to this concentration on subsequent reexamination. The reason for this could not be determined. However the other one remained sensitive even after several generations in the artificial media devoid of penicillin.

Lorian and Sabath $^{5)}$ demonstrated that tubercle bacilli were sensitive to some form 
of penicillins (for example, cloxacillin) and to some combinations of penicllins when the organism was exposed to effective concentrations for long time. They suggested that M. tuberculosis is substantially sensitive to penicillins, but a rapid inactivation of penicillin molecule by spontaneously and by $\beta$-lactamase of the organism of ten make the organism resistant to penicillin. Penicillinresistance of $M$. tuberculosis due to the production of penicillinase has long been demonstrated by many other investigator $\left.{ }^{1,3}, 7\right)$.

Although we did not test the inactivation of penicillin molecules in the media used in this study, the active form of penicillin might be present at enough concentration for long enough duration to inhibit the growth of sensitive organism.

Therefore one of the probable mechanisms related to the development of penicillinsensitive organisms is that such mutant might have evolved from the resistant wild type through a loss or reduction of penicilliase activity. Such a possibility has been proved by observing the reauced activity of penicillinase in our isolate.

We do not know whether this exceptional patient was primarily infected by such unusual organisms or whether some specific factor in this patient favoured development of penicillin-sensitive mutant from a resistant organisms. Further study with a larger number of similar strains will probably answer this question.

※ 本論文의 要旨는 第四次 $\mathrm{APCDC}$ 에서 發表脫으며

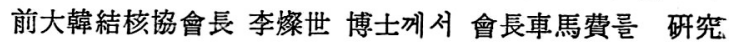

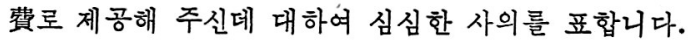

\section{Ref erences}

1. Backelin, B., Lind, A., and Ridell, M. A. new test method for demonstrating Beta-lactamase activity among mycobacteria. Tubercle 54:297, 1973.

2, Canetti, G., Froman, S., Grosset, J., Haun-duroy, P., Langerova, M., Mahler, H.T., Meissner, G., Mitchison, D. A., and Sula, L. Mycobacteria: laboratory methods for testingdrug sensitivity and resistance. Bull. WHO 29: $565,1963$.

3. Dufour, A.P., Knight, R.A., and Harris, H. W. Mycobacterial penicillinase activity. Amer. Rev. Resp. Dis. 94: 965, 1966.

4. Hosty, T.S., Freeman, B., and Irwin, C. Comparative results of penicillin blood agarand Löwenstein-Jensen media in culturing. Mycobacterinım iuberculosis. Publ. Hlth. Lab. 11: 143, 1953.

5. Lorian, V., and Sabath, L.D. The effect of: some penicillins on Mycobacterium tuberculosis, Amer. Rev. Resp. Dis. 105: 632, 1972.

6. Marks, J. Pyruvic acid in the cultivation of tubercle bacilli. Month, Bull. Minist. \& Publ. Hlth. Lab. Serv. 22: 150, 1963.

7. Soltys, M.A. The effect of penicillin on mycobacteria in vitro and in vivo, Tubercle 33: $120,1952$. 